\title{
Relationship between the 1997/98 El Niño and 1999/2001 La Niña events and oil palm tree production in Tumaco, Southwestern Colombia
}

\author{
M. C. Cadena ${ }^{1,3}$, A. Devis-Morales ${ }^{1,2}$, J. D. Pabón ${ }^{4}$, I. Málikov ${ }^{1}$, J. A. Reyna-Moreno ${ }^{1}$, and J. R. Ortiz ${ }^{1}$ \\ ${ }^{1}$ División de Oceanografía, Centro Control Contaminación del Pacífico - CCCP, Vía al Morro, Capitanía de Puerto, San \\ Andrés de Tumaco, Nariño, Colombia \\ ${ }^{2}$ Universidad de Concepción, Cabina No. 9, Casilla 160-C, Concepción, Chile \\ ${ }^{3}$ Instituto de Hidrología, Meteorología y Estudios Ambientales - IDEAM, Carrera 10 \#20-30 piso 7, Bogotá Colombia \\ ${ }^{4}$ Departamento de Geografía, Universidad Nacional de Colombia, Avenida Carrera 30 No. 45-03, Edificio 212, Ciudad \\ Universitaria, Bogotá, Colombia
}

Received: 16 June 2005 - Revised: 14 November 2005 - Accepted: 14 November 2005 - Published: 6 February 2006

\begin{abstract}
Although the relationship between ENSO events and oceanographic and meteorological conditions of Southwestern Colombia is well-known, very little work has been done to assess the related socio-economic impacts. This is the first effort made to determine the effect of such events on local climate and the impact of this variability on oil palm tree (Elaeis guineensis) production in the Tumaco municipality, which is located on Colombia's Pacific coast. First, we studied the correlation between sea surface temperature anomalies (SSTA) in the various El Niño regions and those observed off Tumaco. Next, we scrutinized the ENSO impact on regional climatic indicators, e.g. active solar radiation (hrs/day), air temperature $\left({ }^{\circ} \mathrm{C}\right)$, and rain $(\mathrm{mm})$. Finally, we analyzed the relationship between ENSO, Tumaco climate variability, and oil palm production (tons/hectaremonth). Hours of active radiation increased (decreased) under El Niño (La Niña) conditions, as did average monthly precipitation rates and air temperature. ENSO-related climatic variability also had an important effect on the different developmental stages of the oil palm tree, thereby affecting its production. The worst scenario was found during La Niña, when reduced intensity of the rainy season (second semester) caused severe droughts in the region.
\end{abstract}

\section{Introduction}

Climatic variability affects the development of many human activities, including agriculture. On an interannual scale, ENSO events produce extreme oscillations in the climatic variability of tropical regions; these oscillations have great socioeconomic impacts (Glantz, 1996, 1998). ENSO events have caused economic losses of millions of dollars in the agriculture sector (CAF, 2000). In the Colombian Pacific region, El Niño (La Niña) events typically result in increased (decreased) sea temperatures (up to $150 \mathrm{~m}$ depth) with a direct effect on the mean sea level (CCCP, 2002). Air temperature and rainfall are also enhanced (reduced), affecting the agricultural sector (Pabón, 1990; Pabón and Montealegre, 1992; Montealegre and Pabón, 1992).

The Southwestern Colombian Pacific region is very wet (86\% average relative humidity) and its prevailing conditions, heavy rains and air temperature oscillating between $25^{\circ}$ and $26^{\circ} \mathrm{C}$ (CCCP, 2002), are perfect for cultivating the oil palm tree. Any extreme alteration in these conditions could cause major socio-economic losses. Oil palm tree production is the most important economic activity in the Tumaco municipality, Southwestern Colombia. Regional production is $13.5 \%$ of total national production; Colombia is fourth in worldwide production (Fedepalma, 2004). Even though the importance of this production and the negative effects of La Niña's droughts are well-known (Montealegre and Pabón, 1992; Pabón and Montealegre, 1992; Poveda and Mesa, 1996; IDEAM, 1997), very little work has been done to assess the ENSO-palm tree production relationship.

This paper presents a climatological description of the study area, the main alterations caused by ENSO, and the impacts of the 1997/98 El Niño and 1999/2000 La Niña events on oil palm tree production in Tumaco, Southwestern Colombia. 



Fig. 1. Standardized anomalies of (a) sea surface temperature (SSTA) of the El Niño 1+2 Region and (b) Tumaco for the 19612002 period. Red (blue) colors indicate positive (negative) anomalies caused by El Niño (La Niña) events.

\section{Results and discussion}

\subsection{Methods}

In order to compare an oceanic event such as ENSO with climate and terrestrial production, it was necessary to calculate indexes that normalized all the data into common units. Spectral analysis and correlations were used to compare sea surface temperature anomalies (SSTA) from several El Niño regions with sea surface temperature (SST), air temperature, rain, and active solar radiation anomalies in Tumaco. These climatic anomalies were then compared with an agroclimatic index (Hydro Availability Index, HAI) and with production anomalies from several representative oil palm tree lots.

The oceanographic information corresponded to the monthly mean SST data of El Niño regions for 19602002, provided by the National Oceanic and Atmospheric Agency (NOAA) (http://www.cpc.ncep.noaa.gov/ data/indices). Coastal data was also used in this analysis; monthly means of SST off Tumaco (1960-2002) were provided by the Oceanographical Research Center of Colombia at the Pacific (Centro Control Contaminación del Pacífico, CCCP).

Regional climatologic patterns were established with monthly means for air temperature $\left({ }^{\circ} \mathrm{C}\right)$, rain $(\mathrm{mm})$, and active solar radiation (hrs) taken at 5 stations in the area covered by the 1960-2002 NOAA and CCCP data. This information was complemented with data from pluviometric stations located on the palm tree plantations.

The climatologic station "Granja El Mira" was determined to be the most representative of the entire region; it had the best records available and is located nearest all the crops. It

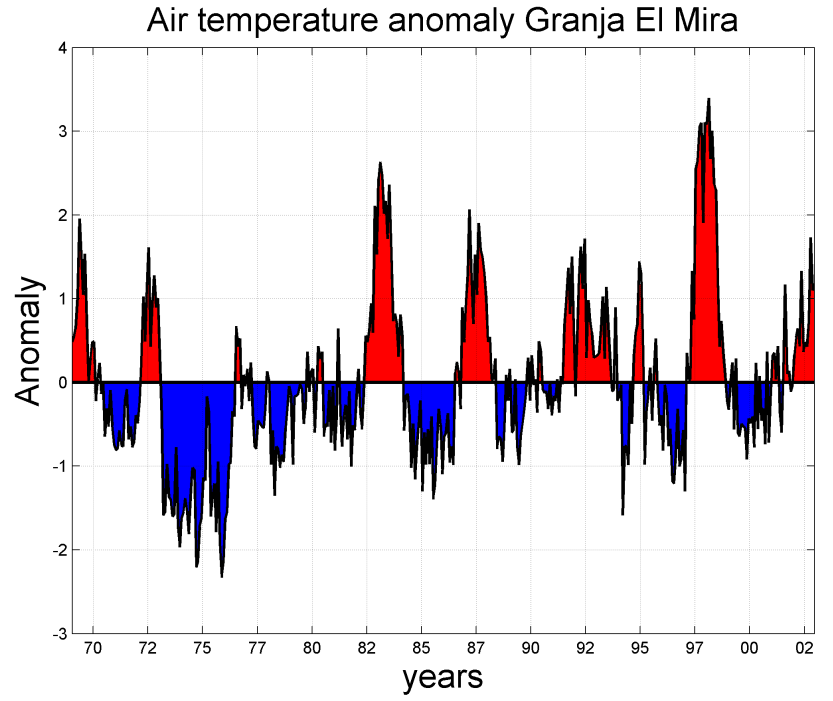

Fig. 2. Standardized anomalies of air temperature (Granja El Mira), for the 1969-2002 period. Red (blue) colors indicate positive (negative) anomalies caused by El Niño (La Niña) events.

was necessary to calculate an agro-climatic index (HAI) from meteorological data (mainly rain). This index relates excess rainwater, with the consumption (evotranspiration) needed during the plant's developmental stages and the rainwater stored in the soils (Appendix A).

Oil palm tree production information (tons per hectare per month; tons/ha-month) was taken from representative lots on several plantations. These lots have been monitored from the crop's initial stages to its current production. Moreover, the Oil Palm Tree Research center (Corpoica) provided data on their lots and production. The lots used in this study are ideal because they have optimal technical management, are of the same seed type, and have stable production. Production information was only available from 1995 to 2002, so comparisons were only possible with ENSO events occurring within this time period.

\subsection{Relationship of ENSO events and climatic variability} in Tumaco

First, we confirmed that the periodicities of Tumaco's oceanographical, meteorological, and agro-meteorological indexes coincided with El Niño Index periodicities (2.8, 3.4, and 5.2 years). The correlation analysis (table not presented here) showed that the SSTA of El Niño Region 1+2 (Fig. 1a) had the highest coefficient $(r=0.74)$ with the Tumaco SSTA (Fig. 1b); the response lag was one month. Similar results were obtained for air temperature $(r=0.83)$ and solar radiation (0.54), but the rain response had a three month delay.

The data also revealed interannual climatic variability in the region due to several El Niño (La Niña) events that produced positive (negative) anomalies in all oceanographic (Fig. 1, lower panel) and meteorological variables (Fig. 2). 


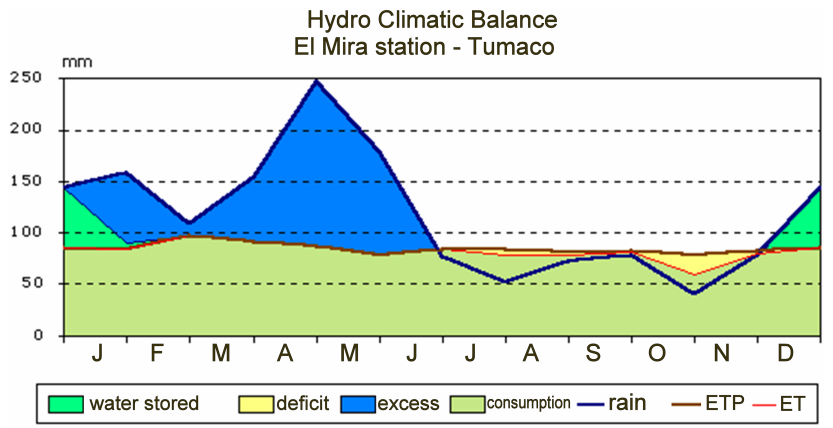

Fig. 3. Hydro-climatic Balance (from Palmer, 1968) of Tumaco (Granja El Mira). During the first and last months of an average year there is storage of water on the soils. The first semester (rainiest indicated by the blue line) has excess of water while during the second semester (less rainy) there is more consumptions (evo-transpiration) that could cause sever droughts.

The 1997/98 El Niño produced a regional increase in rain of nearly $120 \mathrm{~mm} /$ month during both dry (July-December) and wet (January-June) seasons. Conditions were normal during the second semester of 1999 , followed by a reduction in rain of about $40 \%$ during the 2000/01 La Niña event.

Air temperature increased during El Niño by $1^{\circ}(1997)$ and $1.5^{\circ} \mathrm{C}$ (1997), whereas it decreased by $0.5^{\circ} \mathrm{C}$ during the "dry seasons" of La Niña.

Active solar radiation variability behaved similarly, averaging increments of 50 (15) h/month during 1997 (1998) and reductions of $10-20 \mathrm{~h} /$ month for the second semesters of 1999/2001.

Hydric availability was evaluated for different probable rain occurrence scenarios. The HAI was adequate during all decades having normal ( $p: 50 \%)$ and wetter $(p: 25 \%)$ than normal conditions, since rain exceeds evotranspiration. However, for years with less than normal rainfall ( $p$ : $75 \%$ ), the second semester (dry season) could result in severe droughts since evotranspiration cannot be exceed by rain.

During the 1997/98 El Niño, there was an excess of rain in the region $(\mathrm{HAI}>2)$; average rainwater storage in the soils was $200 \mathrm{~mm}$. La Niña, on the other hand, caused a water deficit in the soils (negative HAI values) during the November-December La Niña (Fig. 3). This deficit was reflected in oil palm tree production.

2.3 Relationship between climatic variability and oil palm tree production

The spectral analysis of the production time series coincided with meteorological and agro-meteorological seasonal variability. The first semester, which had higher rainfall, more hours of active solar radiation, and greater air temperatures, was usually the most productive (April-May). Production was reduced during the second semester (AugustSeptember), which had less rainfall.

Although this analysis period was too short to permit the detection of ENSO cycles, the production anomalies

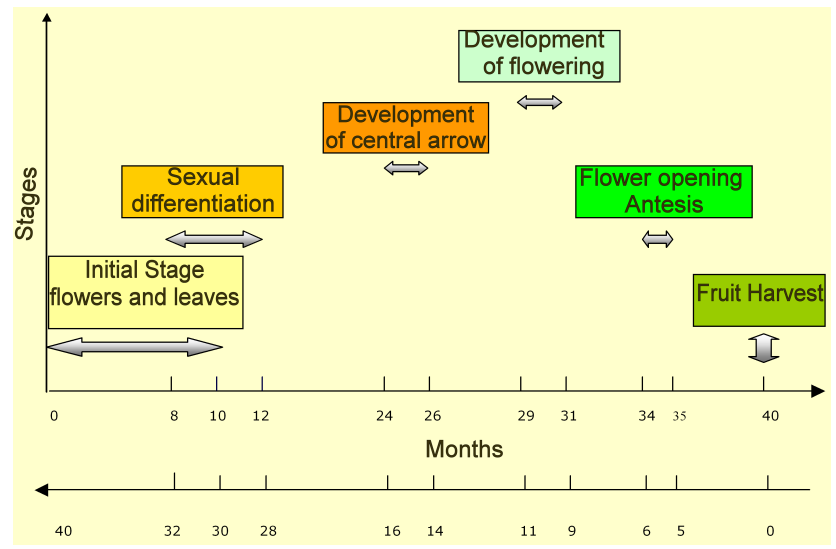

Fig. 4. Oil palm tree life cycle stages from the initial stage $(t=0)$, to the fruit harvest ( $\mathrm{t}=40$ months).

observed at 9 representative lots in the area were crosscorrelated with the climatological and agro-climatological indexes. The latter index shows a 1 to 30 month lag (t1, $\mathrm{t} 2, \mathrm{t} 3 \ldots \mathrm{t} 30)$ that coincided with the crop's different developmental stages (Fig. 4).

Due to its perennial nature, the oil palm tree reacts negatively to unfavorable climatic conditions: evotranspiration is reduced, leaf opening is delayed (first stage), and sexual differentiation is affected (reducing the proportion of femaleproductive vs. male non-productive plants) (Fig. 4). Water is fundamental in sexual differentiation, the development of central arrows, flowering, and fruit production. More female plants are found when the level of solar radiation is good (Corley, 1977).

If any of these requirements are not met, final production will be reduced in the first and consecutive harvests.

Higher (lower) production was observed during and 6 months after periods of enhanced (reduced) precipitation at all productive palm tree lots due to the fruit's accelerated (slowed) maturity (final stages). The same pattern was also observed in the period that corresponds to the initial stages of bunch formation (27 months) and central arrow development (17 months), when the water supply in the soil became the most important factor for future production.

In general, the region of Tumaco had a suitable HAI, since rain exceeded evotranspiration. However, for the years with higher drought probabilities (La Niña events), reduced precipitation in the second semester is accentuated. This deficit could be reflected in the next 3 year's production, which corresponds to bunch development.

High (low) HAI values become important to the plant 17 to 27 months later, owing to a preservation (consumption) of rainwater in the lot soils. This is the period in which the central arrow develops (Fig. 4), which means that an inadequate water supply during this stage will be reflected in low production 2 years later.

The correlation between solar radiation and production was similar to that of rain and production. Air temperature 
Table 1. Annual yields of crude palm oil production (tons/hectare) of Tumaco region (Fedepalma, 2004b).

\begin{tabular}{ccccccc}
\hline Year & 1999 & 200 & 2001 & 2002 & 2003 & Growth rate (\%) \\
\hline Annual yield (tons/hect) & 4.2 & 4.1 & 3.9 & 3.9 & 3.7 & -6.3 \\
\hline
\end{tabular}

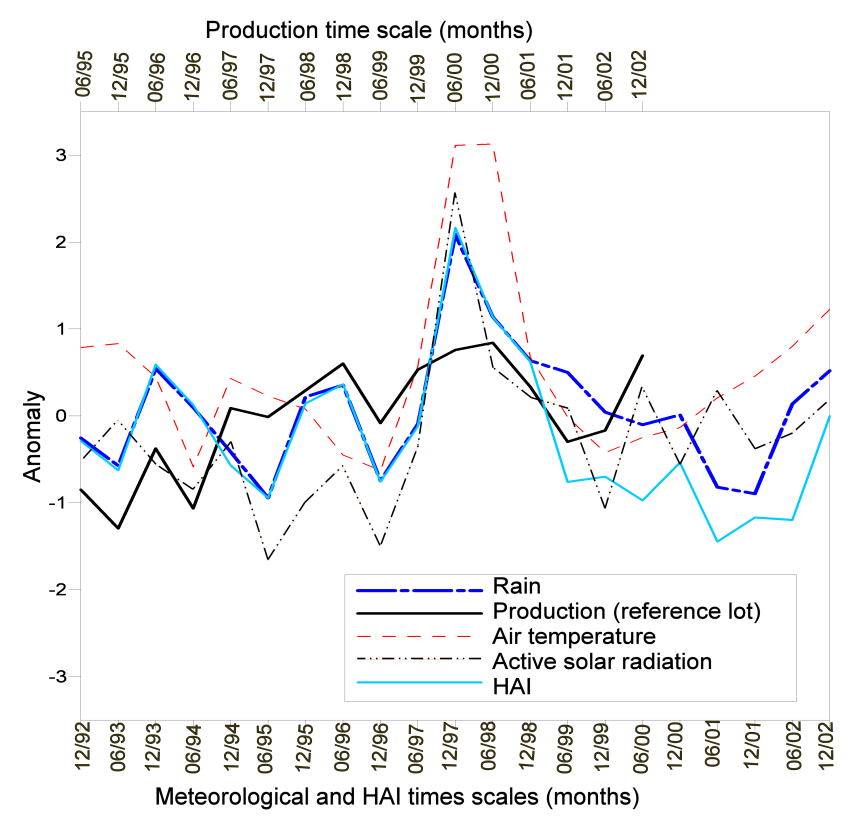

Fig. 5. Highest cross-correlation found $(r=0.86)$ between climatic and agro-climatic anomalies (1992-2002) and production anomaly (1995-2002) at Granja El Mira experimental Lot-Tumaco, Colombia. The meteorological variability of July 1992 affected the January 1995 oil palm production (2.6 years delay), and so on.

had a minor effect on plant production, but was only important in sexual differentiation.

The cross-correlation between climatic variability and long-term production can be seen in Fig. 5, where the production in 1995-2002 is compared with rain, air temperature, active solar radiation, and HAI anomalies from 1992-2002 (lag 2.6 years). Periods of higher (lower) production coincided well with periods of positive (negative) anomalies.

The positive anomalies of the $1997 / 98 \mathrm{El}$ Niño favored the plant's development in its different stages (maturity, anthesis, flowering, central arrow development, and sexual differentiation). These optimal conditions provided an extra energy supply, as observed in the June-December 2000 yields (24 to 30 months after the El Niño event).

On the contrary, the 1999/2001 La Niña produced a $45 \%$ reduction in rain and radiation hours, resulting in reduced production rates for the second semester of 2001.

Due to the limited production data available at the time of this analysis, it was not possible to analyze the second semester of 2002, but based on the 2002 statistical yearbook (Fedepalma), the annual yield of crude palm oil was reduced from 1999 to 2003 (Table 1).

\section{Summary}

Climatic variations had important effects on oil palm production during different stages of the plant's life cycle. The $1997 / 98$ El Niño was highly favorable to oil palm tree production in all its development stages, having a maximum cross-correlation with production 2.6 years later (2000). The 1999/2000 La Niña had the highest negative impact since it occurred during the second semester of the year, causing droughts and reduced oil palm production (2002).

\section{Appendix A}

The agroclimatic variable (HAI) was calculated according to Hurtado (1986). The HAI relates the deficit and excess as follows:

$\mathrm{HAI}=($ Excess $/ 2 * \mathrm{ETP})-($ deficit $/ \mathrm{ETP})$

where ETP is the calculated potential evotranspiration from the modified Penman-Monteith equation (1965; mentioned in Hurtado, 2000). This calculation was based on the methodology of Palmer's Hydric Balance (1968), (in Hurtado and Santos, 1992), in which the water supply represented by precipitation and the demand (or necessary evotranspiration) in the development of the plants is given, as well as the water stored in the ground.

The HAI ranges from:

$\mathrm{HAI}>2$ : very wet

$2>\mathrm{HAI}>1$ : wet

$1>\mathrm{HAI}>0$ : normal

$0>\mathrm{HAI}>-1:$ dry

$-1>\mathrm{HAI}>-2$ : very dry

The parameters required for the calculation were obtained from the hydric balance per decades of the Granja El Mira station for 1969-2002. The Palmer technique considers a two-layer ground profile: the superficial layer, in which water extraction is made on a potential scale; and the deep layer, in which the extraction is proportional.

The parameters derived from the hydric balance of the ground are:

ALMS - present storage in the superficial layer

ALMP - present storage in the deep layer

ALMT - (ALMS+ALMP); ET - real evotranspiration

$\mathrm{ESC}$ - run-off or excess water

$\mathrm{DEF}$ - water deficit

$\mathrm{R}=\mathrm{ET} / \mathrm{ETP}-$ yield index (satisfactory if $\mathrm{R}>0.6$ ) 
Once the series of the agroclimatic index (HAI) were obtained, the same procedure was applied to calculate the standardized anomalies.

With the anomaly series, analyses and correlations were carried out in order to establish the effect of the climate and its repercussion on the development of oil palm tree cultivation.

Edited by: P. Fabian and J. L. Santos

Reviewed by: M. Holgrem and J. L. Santos

\section{References}

CAF: Las lecciones de El Niño, Memoria del fenómeno El Niño 1997-1998. Retos y propuestas para la región andina. Volumen III, Colombia, Ex Libris, Caracas, Venezuela, 242 pp., 2000.

Centro Control Contaminación del Pacífico (CCCP): Compilación oceanográfica de la Cuenca Pacífica Colombiana, Imágenes de la Naturaleza Editores, Tumaco, 109 pp., 2002.

Corley, R. H. V.; Oil palm yield components and yield cycles, in: Internacional developments in oil palm, edited by: Earp. D. A. and Newall. W., Incorporated Society of Planters, Kuala Lumpur, 116-129, 1977.

Fedepalma: Economía y mercados, Geografía palmera, Nariño, Mapa, Cultivo de palma de aceite, www.fedepalma.org, 2004a.

Fedepalma: Statistical Yearbook 2004, 122 pp., www.fedepalma. org, 2004b.
Glantz, M. H.: Currents of Change, El Niño impact on climate and society, Cambridge University Press, Cambridge, 208 pp., 1996.

Glantz, M. H.: Full Summary of Review of the Causes and Consequences of Cold Events: A La Niña Summit, 15-17 July/1998, Boulder Colorado, http://www.esig.ucar.edu/lanina, 1998.

Hurtado, G.: Índices de sequía y su aplicación operativa en Colombia, Revista Atmósfera No. 5, Sociedad Colombiana de Meteorología, Marzo, 1986.

Hurtado, G. and Santos, L.: Agrometeorología aplicada a la adecuación de tierras, 43 pp., 1992.

Hurtado, G.: La evapotranspiración potencial en Colombia, IDEAM, 35 pp., 2000.

Montealegre, J. E. and Pabon, J. D.: Interrelación entre el ENOS y la precipitación en el Noroccidente de Suramérica, Boletín ERFEN, (31), pp. 3-11, 1992.

Pabón, J. D.: Efecto climático del fenómeno El Niño en el suroccidente colombiano, in: Memorias del IV Congreso Interamericano y II Colombiano de Meteorología., Septiembre 17-21, Bogotá, 161-168, 1990.

Pabón, J. D. and Montealegre, J. E.: Manifestación El Niñooscilación del sur (ENOS) en la costa Pacífica colombiana, Boletín ERFEN, 31, 3-11, 1992.

Poveda, G. and Mesa, O.: Caudales Medios Mensuales de Ríos Colombianos durante El Niño y La Niña, in: Memorias del IV Congreso Colombiano de Meteorología, IDEAM-SOCOLMET, 291-298, 1996

http://www.cdc.noaa.gov/ClimateIndices

http://www.cpc.ncep.noaa.gov/data/indices/ 